\title{
Peripatetic Readers and a Dancing Maiden: Marginal Multigraphic Discourse in a Medieval Latin Multiple-Text Manuscript
}

\begin{abstract}
Triggered by an encounter with a drawing of a foot among the pointing hands that scholars usually take for granted in medieval manuscripts, this contribution analyses the layers of pictorial and written paracontent in a scholarly manuscript from the second half of the thirteenth century, Schlatt, Eisenbibliothek, MSS 20. In the rubricators' and illuminators' contributions, a playful discourse unfolds that reflects on contemporary concepts of reading and shapes the way that later users read the contents and left their mark on the manuscript.
\end{abstract}

\section{Introduction}

Manicules, drawings of hands with extended index fingers, are a familiar sight in the margins of medieval and early modern European books. Drawn by scribes or, more often, by readers, they usually serve to highlight particular passages of text and are therefore both traces of use and significant elements of a book's visual organization that guide the reader's interaction with the book and its contents. It is rare, perhaps unique, to find among the manicules in a book a little foot - a pedicule, so to say - daintily perched on the end of the last word of a line (Fig. 1). The line belongs to a paragraph that marks the conclusion of the pseudo-Aristotelian De secretis secretorum in a manuscript dated to the second half of the thirteenth century, Schlatt, Eisenbibliothek, MSS 20. ${ }^{1}$ When readers turn four more leaves, they encounter a second foot, attached to a verticallypositioned line of a rubric as if to a leg. The function of the feet is revealed on reading the rubric: 'Incipit liber $5^{\text {us }}$ liber $[s i c]$ de secretis secretorum aristotelis • et vadis ad tale signum in $4^{\circ}$ folio superius' - 'Here begins the fifth book of

\footnotetext{
1 A digital reproduction of the entire manuscript is available at $<\mathrm{https} / /$ www.e-codices.ch/de/ list/one/ebs/0020> (accessed on 18 Jan. 2021). On the manuscript, see Gamper and Marti 1998 (reproduced in the description accompanying the digital reproduction); Gamper 1998; Volpera 2018; and Flüeler 2020. As the description of the manuscript in Gamper 1998, by and large, follows the more detailed description in Gamper and Marti 1998, Gamper 1998 will henceforth be cited only in cases when it diverges.
} 
Aristotle's De secretis secretorum, and you go to such a sign on the fourth leaf above'. The choice of feet as cross-reference signs resonates beyond the playful pictorial pun on the rubricator's words that send the reader on a journey across the pages to find the correct place for the text. As a book-maker's mark, the pedicules are part of contemporary practices of book production while also commenting on medieval scholarly practices of book use and scholastic concepts of reading. They are elements within a network of communication between various individuals who left their mark on the leaves of this book: a team of producers who collaborated, very closely at times, and a number of users who responded to the written and drawn contents and paracontents of their manuscript.

\section{The manuscript and its Aristotelian part}

The sole medieval manuscript in the Eisenbibliothek's collection offers an example of both the challenges and rewards that what Peter Gumbert has termed a 'non-homogenous codex' holds in store for scholars. ${ }^{2}$ The manuscript, comprising one hundred leaves and measuring $23.5 \times 15.5 \mathrm{~cm}$, has three distinctive parts. Physically separated by quire breaks, they are heterogeneous in terms of their contents, their scribes, and details in their visual organization. The first part contains a series of treatises mostly spuriously attributed to Aristotle: $D e$ secretis secretorum, De planetis (labelled as part of De secretis secretorum), De pomo, De coloribus and De motu animalium (two short, genuinely Aristotelian treatises), Physiognomia, De bona fortuna, and De lineis indivisibilis (the attribution of the last two to Aristotle having stood the test of time). At least two scribes are distinguishable, the change of hands coinciding with a quire boundary and the beginning of a new treatise, Physiognomia (fol. $25^{\mathrm{r}}$ ). These are not the texts at the heart of the scholastic university curricula. ${ }^{3}$ They were, however, widely read in the thirteenth and fourteenth centuries, in particular De secretis secretorum, which claims to have been written by Aristotle for his former pupil Alexander the Great. It covers a wide range of subjects, from wise rulership and prudent behaviour in general, to astrology, diet, and hygiene, ${ }^{4}$ some of which

2 Gumbert 2004, 18.

3 Compare e.g. Weisheipl 1964; Grabmann 1934.

4 The De secretis secretorum presents itself as advice to a king, and manuscripts containing it are known to have been presented to rulers, e.g. London, British Library, Add. MS 47680, given to the young King Edward III by his advisor Walter de Milemete; see Sandler 1986, n. 85 and the 
are further explored in the following treatises, especially De planetis, De pomo, and Physiognomia.

The second part contains two treatises by Albertus Magnus and a fragment of one by Avicenna, written by one scribe. The third part, written in its entirety by a fourth scribe, is a collection of commentaries on philosophical texts and another short Aristotelian treatise, De inundatione Nili. ${ }^{5}$ The contents are invariably in the latest translation and accompanied by paracontents such as prologues that had been composed as recently as the 1250 s. $^{6}$ Beyond a general interest in up-to-date scholarly publications on a rather broad range of topics, mostly from the fields of natural philosophy and ethics, however, little can be discerned that connects the contents of the three parts particularly closely. They may well have been conceived as individual or separate codicological units, ${ }^{7}$ and, beyond the bi-columnar mise en page and similar dimensions of the written area, their scribes used different patterns for the visual organization of the text. ${ }^{8}$ The parts must have been joined together not very long after they were

digital reproduction at <http://www.bl.uk/manuscripts/FullDisplay.aspx?ref=Add_MS_47680> (accessed on 12 Jan. 2021). As demonstrated by Williams 2003, however, the treatise was known and read in much wider circles. The title of Gamper's article, 'A compendium fit for a king' ('Ein fürstliches Kompedium'; Gamper 1998) may therefore be misleading. While the use of historiated initials and gold-leaf make this an expensive manuscript, many similarly lavish Aristotle manuscripts have come to light since the time of Gamper's publication, showing that expensively illuminated manuscripts of 'the Philosopher's' works had become covetable status symbols to many well-heeled learned individuals and institutions; see Wimmer 2018.

5 Albertus Magnus, De mineralibus (fols $33^{\mathrm{r}}-61^{\mathrm{v}}$ ); De natura loci (fols $62^{\mathrm{r}}-79^{\mathrm{v}}$ ); Avicenna, De anima (prologue only, fol. $80^{\mathrm{r}}$ ); the commentaries in the third part of the manuscript are Michael Scot's on Johannes de Sacrobosco, De Sphaera (fols $81^{\mathrm{r}}-93^{\mathrm{v}}$ ); an anonymous commentary on Boethius, De arithmetica (fols $94^{\mathrm{r}}-99^{\mathrm{r}}$ ); and Averroes' Compendia on Aristotle's Parva naturalia , labelled here as Ptolemy's commentary on Aristotle's De longitudine et brevitate vitae (fols 99 $-100^{r}$ ); Gamper and Marti 1998.

6 Gamper and Marti 1998.

7 Peter Gumbert defines this useful term as 'a discrete number of quires, worked in a single operation [...], containing a complete text or set of texts (unless it is an unfinished, defective or dependent unit)'; Gumbert 2004, 40.

8 On the differing line numbers and lining techniques, see Gamper and Marti 1998. It may be added to Gamper and Marti's observations that unlike the other scribes, the scribe of the first section left no space for the initials that mark the beginnings of chapters within the left columns, and minimal indentations, two lines high, in the right column. Accordingly, the initials were inserted outside the column, in the margin and in the intercolumnium. The latter is so narrow that the slight indentations were crucial to allow the rubricator enough space. Placing initials outside the script column, except in verse texts, appears to be more common in Northern Italian manuscripts than in those from large centres of production in Northern Europe. See e.g. London, British Library, Add. MS 18720/2 (a bible from Bologna, late thirteenth century); 
written, however, as the final touches - the rubrication and the sumptuously illuminated initials adorned with gold leaf - were applied to them in a single workshop, probably in the second half of the thirteenth century. ${ }^{9}$ Two illuminators and at least two rubricators were at work. The question of where their workshop was located is made more difficult by the fact that the two illuminators represent very different artistic traditions. ${ }^{10}$ Most recently, it has been suggested that the manuscript was illuminated in a workshop in Genoa that may have been connected with the local Dominican monastery. ${ }^{11}$

The producers' differences in style highlight the ways in which they worked together to finish and visually tie together the three parts of the manuscript, to articulate the structure of their contents visually, from the treatise as a content unit down to a book chapter, and accordingly to make them easily accessible to their readers. ${ }^{12}$ Many treatises in the Aristotelian part, as well as their various books, open with large historiated initials with images that refer to the title or contents of the text, which makes them particularly effective finding aids. ${ }^{13}$ The other content units begin with ornamental initials painted in tempera colours or, in the case of the commentaries in the third part, in blue and red ink. While, as Federica Volpera has argued, the historiated initials were probably based on existing models, the resulting distinction of the works by scholasticism's most important philosopher over those of his later commentators and contemporary scholars is found in many other manuscripts of the time. ${ }^{14}$

London, British Library, Harley MS 5266 (Euclid's Elements, Northern Italy, early fourteenth century). Digital reproductions of both manuscripts are available at <http://www.bl.uk/ manuscripts/Default.aspx> (accessed on 12 Jan. 2021). This appears to strengthen the hypothesis that the manuscript (or another of its various parts and production layers) is of Italian origin. In the same part of the manuscript (fol. $24^{v}$ ), a scribe's signature uses the Italian rather than the Latin spelling of 'dextera' in his signature: 'Ego frater Guifredus scripsi hoc opus. Scriptorem libri conservet gratia Christi. Auxilio cuius destera scripsit opus'; Gamper and Marti 1998.

9 Volpera 2018, esp. 44-45; Gamper and Marti 1998.

10 Gamper and Marti 1998; Volpera 2018, 44.

11 See Volpera 2018, 38, with references to previous research on manuscript production in Genoa, and Flüeler 2020.

12 On the visual organization of scholarly manuscripts since the later twelfth century and its functions, see e.g. Parkes 1976; Illich 1993; Rouse and Rouse 1982; and Wimmer 2018, esp. 33-50.

13 On the iconography of the historiated initials and their reference to the text, see Volpera 2018, 39-42.

14 On the similarities of the depictions in the initials of De secretis secretorum with those of other extant manuscripts containing the treatise, see Volpera 2018, 39-42. Many manuscripts that include historiated initials for Aristotelian works do not do so for all his treatises, and texts by more recent or even living authors are significantly less frequently afforded this distinction. 
It is difficult to reconstruct the exact order in which the two illuminators and rubricators worked. Evidently, however, the work was not simply shared as it was between the scribes, each working on a separate section or quire. The first illuminator, who painted the historiated initials, has a repertoire of motifs familiar from Northern European manuscript painting, with its characteristic leaftailed dragons in the border extensions. The second was trained in an Italian style. ${ }^{15}$ Volpera has pointed out that not only did the two illuminators occasionally draw on each other's repertoire of motifs, suggesting that they were working in the same workshop at the same time, but that in some cases, both contributed to the same initials. ${ }^{16}$ In these instances, the second illuminator added ornamental extensions or elaborate border bars to historiated initials previously painted by the first illuminator. Given the manuscript's probable Italian place of production, the addition of the Italian-style elements to the initials may have been a nod to the unknown commissioner's tastes. There is, however, another possibility. The additional marginal extensions of the historiated initials may not have been randomly added to some initials and not others: rather, they appear to systematically introduce a visual difference among the initials painted by the 'French'-style illuminator. They distinguish the beginnings of treatises from those of books, the latter being left without or with only the minimal border extensions provided by the first illuminator. While this may conceivably have been a collaboration planned from the start, it seems more likely that it represents a process of tweaking and revising the visual organization of the manuscript.

The rubrics also play an important role in the organizational scheme of the manuscript. Like the illuminators' work, the two rubricators' contributions are not separated by text or quire boundaries but are found across the Aristotelian part (and beyond), and sometimes on the same page. The first rubricator executed almost the entire rubrication of the manuscript, perhaps including the numerous red and blue pen-flourished initials and simple paragraph signs that indicate chapter beginnings and other caesurae in many of the texts. His rubrics are written in a neat gothic book hand, in carefully spaced, regular lines. The second rubricator payed much less attention to the aesthetic quality of his

See Wimmer 2018a, App. II, 349-366, for an overview of the distribution of historiated and illuminated initials in seventeen manuscripts containing Aristotelian works on natural philosophy from the latter half of the thirteenth and early fourteenth century.

15 Gamper and Marti 1998.

16 Volpera 2018, 45. 
writing, which has a less formal appearance and is smudged in some places. ${ }^{17}$ While the first rubricator carefully erased pen-flourishes of a neighbouring initial to make space for his incipit note (fol. $2^{r}$ ), the second rubricator frequently wrote across the pen flourishing of chapter initials and, once, his writing overlaps the black outline of a historiated initial (fol. 14v ; Fig. 1). ${ }^{18}$ The rubrics written by the second rubricator must therefore have been added at a very late point in the production process, either at the very end or while the other producers were still working on other quires.

It appears that the second rubricator's work was more specialized than his collaborator's. In the entire manuscript, his hand is only found in the rubrics of Aristotelian or pseudo-Aristotelian treatises in the first part of the manuscript and Aristotle's De inundatione Nili at the very end of the third..$^{19}$ In particular, it is the subsections, books and chapters, where most of his contributions are found. These seem to have caused the first rubricator some difficulties. Problems started on the first pages of De secretis secretorum, where there was confusion about the prologues to the treatise. The scribe left blanks for large initials at the very beginning, i.e., the beginning of the translator's, Philipp of Tripoli's, prologue (fol. 1r), and again at the beginning of the prologue purportedly by Aristotle (fol. 1v). On some pages, the instructions that the scribes of the Aristotelian section left for the rubricators are still visible along the lower edges, but no traces of such instructions remain here. The rubricator correctly identified Philipp's prologue in the rubric next to the historiated initial (albeit labelling it as a prologue by bishop Guido of Valencia, who is mentioned in the preface as the commissioner of the translation). He then marked the second section, introduced by a red pen-flourished initial, as 'alter prologus' ('another prologue'). He had to write in the margins as the scribe had evidently not envisaged a rubric here, and therefore left no space for it in the column. A lengthy rubric at the beginning of the preface supposedly by Aristotle was deleted and replaced by

17 See, for instance, his entry 'capitulum 13um' on fol. $3^{v}$, where the first letter appears smudged and an incorrect chapter number was struck through before adding the correct one. See also the rubric on fol. $17^{\mathrm{v}}$ (Fig. 2 below).

18 Instances of the second rubricator's writing overlapping pen-flourished initials are numerous; see e.g. fols $4^{\mathrm{v}}, 8^{\mathrm{r}}, 8^{\mathrm{v}}$. The rubric introducing what is labelled tentatively as Book VI of the De secretis secretorum on fol. $14^{\mathrm{v}}$ visibly overlaps the historiated initial.

19 Gamper and Marti 1998 interpret this as a sign that the first part of the manuscript was rubricated and illuminated last, inferring from the evidence that the second rubricator started his work only when the second and most of the third part had already been rubricated. Volpera 2018,49, n. 7 , rightly cautions that given the evidently complex ways in which the illuminators and rubricators collaborated on the Eisenbibliothek manuscript, this argument may not hold. 
the single word 'prologus' (fol. $1^{\mathrm{v}}$ ). The following rubric, which correctly identifies the beginning of Book I of De secretis secretorum (fol. $2^{\text {r }}$ ), is the last one that the first rubricator added in the treatise. He only took over again for the marking of the prologue and the beginning of De pomo. Picking up where the first rubricator left off, the second added chapter numbers in Arabic numerals. Wherever he could, he inserted these in the remaining space of the line that preceded the new chapter, which always starts with a pen-flourished initial in a new paragraph. If this was not possible, he added them in the margins. In the blank spaces next to the initials at the beginning of the individual books, he noted down the end of the previous and the beginning of the next. Here, too, he encountered irregularities, as expressed in the rubric on fol. $14^{\mathrm{v}}$ (Fig. 1): 'Explicit 5us liber de secretis aristotelis. Incipit 6us liber de secretis aristotilis secundum quosdam quod non credo' - 'Here ends the fifth book of Aristotle's De secretis [secretorum]. Here begins the sixth book of Aristotle's De secretis [secretorum] according to some, which I do not believe'. No traces of instructions remain in the bas de page. It appears, however, that the scribe (or the one of the manuscript that he consulted) did not believe it, either: the paragraph at the end of Book IV declares the treatise 'completus'. The rubric furthermore, if only implicitly, signals that there is content missing here: Book V does not end here as it is missing. ${ }^{20}$ When the second rubricator wrote the rubric, he probably already knew that the book appeared later on in the manuscript, and that he would redirect the reader accordingly.

At the end of the second treatise, De pomo, two substantial sections of text that had been omitted from De pomo and De secretis secretorum, respectively, were inserted (fol. $17^{\mathrm{v}}$; Fig. 2). Both rubricators were involved in the task of labelling and assigning them their proper positions. The first amendment on the page is a prologue to De pomo. The first rubricator, who had written the rubrics for this treatise, substantially elaborated on the scribe's short note in the bas de page, 'Prologus super librum de pomo', extending his rubric outside the allocated space into the intercolumnium: ${ }^{21}$

Incipit quidam prologus super librum aristotelis de pomo et pones istum prologum ad tertium folium retro ubi incipit alter prologus super librum aristotelis de pomo qui sic incipit • cum clausa esset via ad tale signum.

20 Gamper and Marti 1998 erroneously read the note as the incipit to Book V.

21 The left edge of the page with beginning of the note has been cropped away, leaving '[...]gus super librum de pomo'. 
Here begins a certain prologue to Aristotle's Liber de pomo; and you place this prologue on the third leaf above where another prologue on Aristotle's Liber de pomo begins, which begins thus: 'Cum clausa esse via', at such a sign.

The manicule that he chose as the cross-reference sign was initially begun next to the space left for the rubric in the script column, where a red line delineates an index finger and thumb. A finished version is placed at the very end of the rubric, immediately after the word 'signum'. The instructions to the reader are precise and accurate, using not one, but three means of codex-navigation: counting three leaves backwards, on fol. $15^{\mathrm{v}}$, ones finds a second red manicule in the left margin, next to a pen-flourished initial that marks a section of text beginning with 'Cum clausa esse via'. The second amendment on fol. $17^{\mathrm{V}}$ is Book V of De secretis secretorum. It is introduced by the rubric with the pedicule, quoted in full above. Written by the second rubricator. it also expands

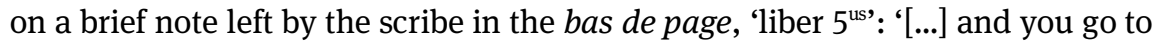
such a sign on the fourth leaf above'. Again, the reader is provided with precise instructions about where to find the correct place for the text, which should have started on fol. $14^{\mathrm{v}}$. The sign of the foot, in picking up the metaphor of going or walking ('vadis'), playfully refers to the wording of the rubric, to its own function as a cross-reference sign, as well as to the little hand further up on the same page. It is very likely that another workshop member got involved here. Unlike the red manicule, the feet are not drawn in the rubricator's ink, but in brown ink. Furthermore, the neatly and precisely delineated shape of the feet contrasts with the casual writing. The red paragraph mark opposite the little foot on fol. $14^{v}$ (Fig. 1) with its slightly irregular outline is more in keeping with the style of the second rubricator's handwriting; perhaps this was his first version of a reference sign.

\section{Hands: Manicules and the embodied reader}

Despite being such a familiar sight, the manicule has only relatively recently received some well-deserved scholarly attention. ${ }^{22}$ The pointing hand, often attached to a wrist, an arm, and occasionally to an entire body, is rich in rhetorical and iconographic references, ranging from an indicating gesture to the rhetor's raised finger that stresses a point, to the allusion of the teacher's spoken word and not least to the reader's own page-turning, line-tracing, and

22 Sherman 2008, Chapter 2: 'Towards a History of the Manicule'. 
penwielding hand. ${ }^{23}$ It is also perhaps unique, as Bill Sherman has proposed, in fitting all three of Peirce's categories for signs: 'it is at once icon, index, and symbol' ${ }^{24}$ In a stylized form, it was relatively easy and quick to draw, while also inviting variation and individualisation. ${ }^{25}$

As the depiction of a body part involved in the manipulation of the book, the manicule alludes to the fact that in the Middle Ages, reading was thought of as an activity that was both physical and intellectual involving, in the terminology of medieval scholarship, both the outer and the inner senses. ${ }^{26}$ The monastic contemplative reading practice, the lectio divina, demanded the repetitive reading-out-loud of the sacred texts to commit their words to memory, a process referred to as ruminatio. ${ }^{27}$ To what extent the physical engagement with the book and its contents was transcended in the process of reading was thought to depend on degrees of erudition, discipline, and spiritual yearning, as well as on gender. ${ }^{28}$ It is perhaps not surprising that in some medieval European manuscripts, marginal manicules are joined by eyes, adding a reference to the gaze: heads, sometimes human, sometimes animal or fantastical, turn wide-eyed towards the text. ${ }^{29}$ The hands and eyes appear to be pictorial equivalents of the numerous marginal written notes that instruct readers to 'nota (bene)', 'take note!', a term which refers both to making a physical mark and to mentally retaining something, and 'ecce', 'look!' ${ }^{30}$ The drawings are, however, visually

23 Sherman 2008, 24-52. As Sherman puts it, manicules 'have an uncanny ability to conjure up the bodies of dead writers and readers'; Sherman 2008, 29. For a short introduction to the role of the hand as an instrument of communication from a cultural-historical perspective, see e.g. Pompe 2003, with further bibliographical references.

24 Sherman 2008, 51.

25 Sherman 2008, 36, points out that some early modern readers' manicules are as distinctive as their signatures. In some medieval manuscripts, meanwhile, the apparent aim was variation in the repertoire of manicules. This may well have been the result of individual preference, but also perhaps helped readers to more easily distinguish between the various passages they highlighted.

26 Sherman 2008, 47-49. On medieval reading practices, see e.g. Illich 1993 and Saenger 1982.

27 See Illich 1993, 54-55; Carruthers 2005, 165-170, 219-220.

28 On medieval notions about men's and women's reading, see e.g. Solterer 1994.

29 A rich variety of 'pointers' and 'gazers' is found, for instance, in a fourteenth-century manuscript of English origin containing La lumere as lais, New York, Pierpont Morgan Library, MS M. 761; see Sandler 2012. Another English manuscript, containing mostly Aristotelian treatises on logic and dated to the early fourteenth century, London, British Library, Royal MS 12.D.II, has numerous marginal drawings, among them many pointing hands and exaggerated gazes.

30 In London, British Library, Royal MS 12.D.II, the googly-eyed monsters and wide-eyed human figures in the margins are often accompanied by a marginal note beginning with 'ecce'. 
more striking than written words. ${ }^{31}$ Their pictorial quality immediately draws the reader's eye to the place where the noteworthy passages are. Like the 'nota bene' and 'ecce' notes, however, they differ in their function from those marginal annotations - usually written, but sometimes also pictorial ${ }^{32}$ - that sum up or comment on the content of a passage. Their function is purely to indicate, not to communicate content themselves. This function makes them a distinct category within the marginal paracontent of a manuscript, and this is, in turn, important for their effective functioning: a reader seeing a manicule in the margin will hardly expect to find a discussion on hands.

The red manicule in the Eisenbibliothek manuscript is not a reader's but a maker's mark, not only because it is drawn in the rubricator's red ink but also because its function is not to emphasise, or make easily retrievable, a section of the content (Fig. 2). Instead, it serves to highlight an editorial change, a correction, and helps the reader understand where the addition should be inserted. Using reference signs to precisely anchor corrections was a well-established practice in thirteenth-century Europe. Manicules are not, however, among the repertoire of symbols that are normally used in this context. Rather, correctors used combinations of simple geometric shapes, letters, and punctuation signs that could easily be varied..$^{33}$ Perhaps the rubricator of the Eisenbibliothek manuscript felt that a major correction merited a more sizeable and visually striking reference sign and chose a shape familiar to him; perhaps his eye fell on the correction in the first line of the column, where a corrector had amended the word 'manus', 'hand'. Be this as it may, in its current context, the rubricator's manicule changes (or rather expands) its conventional meaning somewhat. While its counterpart three leaves above indicates the precise point where the additional prologue should have been, the hand that is part of the rubric can also be understood as a reference to the rubric's appeal to the reader's active contribution to setting the jumbled order of the texts to right. The reader's adjusting the order of the text as he reads is thus likened to a manual reshaping of

31 Marginal 'nota' often form more or less elaborate and ornamental ligatures that are instantly recognisable word-images. Arranged in a way that connects the letters to the much elongated stem of the 't', these nota ligatures also lend themselves to being used as a kind of visual bracket to indicate the length of the highlighted passage (e.g. on fol. $7^{\mathrm{v}}$ of the Eisenbibliothek manuscript).

32 On 'scribal drawings', see Sandler 2012, with further bibliographic references. For pictorial glosses in manuscripts containing legal texts, see also Fronska 2019; for instances of pictorial glosses in Aristotle manuscripts, see Wimmer 2018a, 134-136 and Figs. 66-68, and 150-151 and Fig. 75.

33 See e.g. an insertion in the margin of fol. $2^{\mathrm{r}}$ in the Eisenbibliothek manuscript. 
the manuscript by reordering its building blocks. In an English book of hours from around 1300, this metaphor is given a striking visual form. ${ }^{34}$ In the manuscript, entire verses that were initially omitted were added above or below the written area. Little painted 'correction workers' in the margins drag the verses in place. ${ }^{35}$ On one page a painted male figure is holding on to a long penwork tendril as if it were a rope with one hand, the long index finger of the other hand pointing at the place where the verse should be inserted (Fig. 3). A second man, seemingly emerging from an initial, is extending his hands, ready to receive the tendril from the first. Here, the first labourer's gestures combine the two actions that the manicules in the Eisenbibliothek manuscript perform and ask the reader to perform, respectively: indicating the correct position where a section of text should be placed, so as to allow the reader to re-order the elements in his reading process.

\section{Feet: Pedicules and the mobile reader}

Unlike the reader of the book of hours, the reader of the Eisenbibliothek codex cannot implement the corrections at a glance but has to turn several leaves in order to do so. The rubric of the second major insertion, accordingly, sends the reader on a journey, and the sign chosen to mark the beginning and end of this journey reinforces the prominence of this metaphor.

While feet, unlike hands, are exceedingly rarely used as reader's (or scribe's) marks, the metaphor of the reader's interaction with the book and its contents' being a journey was well-known in the Middle Ages. It is only relatively recently, however, that scholarship has explored the extent to which the codex as a material object lent itself to reinforcing the experience of reading as a perambulation of what is not just a metaphorical literary space but quite concretely a spatially organized material object. As Bruno Reudenbach has shown, the codex with its sequence of two-page openings, in contrast to the scroll, has a strong spatial dimension. ${ }^{36}$ The notion of the codex as an articulated space through which the reader moves while progressing through its contents is one

34 On the manuscript, see <https://www.thedigitalwalters.org/Data/WaltersManuscripts/html/ W102/description.html $>$ (accessed on 12 Jan. 2021), including a digital reproduction of the manuscript.

35 On the medieval 'correction workers' in this manuscript, see e.g. Camille 2010, 24, with a reproduction of the second instance of this motif in the manuscript.

36 Reudenbach 2009, 60-61. 
that shaped readers' experiences, and the visual organization of codices, throughout the Middle Ages. ${ }^{37}$

In the Getty Apocalypse, made in England in the 1260s, the figure of John, the witness to and narrator of divine revelation, appears on every page (Fig. 4)..$^{38}$ At times within the frame of the miniature as part of the events, but often outside the frame in the margin as an eager and engaged onlooker, he acts as an intermediary and model for the reader-viewer. ${ }^{39}$ In many of the images, he is holding a walking stick that identifies him as a traveller. His experiences that culminate in his vision of the New Jerusalem, and by analogy the reader's experience, are thus characterized as a spiritual pilgrimage. ${ }^{40}$ This journey on which John guides the reader is very much presented as a journey that unfolds, page by page, through the codex.

The pedicules in the margins of the Eisenbibliothek manuscript allude to the codex as a space, but unlike in the Getty Apocalypse, the activity of walking is not likened to the process of reading. Instead, it refers to the finding of a specific section of text, in a specific place in the codex, to which the reader is guided with precise instructions and signposts. This kind of walk in search of a particular place appears to have more in common with medieval (and ultimately antique) conceptions of memory and its retrieval, in particular in the trained memory of a scholar (or rhetor). The efficient retrieval of something previously memorized was 'fantasized as a bodily rush to the appropriate part of one's mental architecture' where it had been deliberately placed and carefully labelled. ${ }^{41}$ At a time when the space of the book was expected to be sufficiently clearly organized to allow easy access to its various contents, this metaphor of walking-to-retrieve could be transferred to the physical manipulation of the book as much as to the navigation of its contents.

37 See e.g. Tumanov 2015 on later medieval devotional reading practices. On the spatial qualities of the double-page opening, see Hamburger 2009; Schneider 2000, 2009; Wimmer 2018b. 38 On the Getty Apocalypse, Los Angeles, J. Paul Getty Museum, MS Ludwig III 1 (83.MC.72), see e.g. Morgan 1988, 98-100, no. 124; Lewis 1992. A digital reproduction of the manuscript is available at <https:/www.getty.edu/art/collection/objects/1360/unknown-commentary-byberengaudus-getty-apocalypse-english-about-1255-1260/> (accessed on 18 Jan. 2020).

39 Lewis 1992, 56-61.

40 See Lewis 1992, 59.

41 Illich 1993, 42. On the medieval art of memory and the important role that spatial structure and organization play in it, see also Carruthers 2005, esp. 43-44, 221, 242-246. 


\section{A dancing girl and a poison-maiden: Makers' marks and readers' reactions}

The witty invention of the foot as an editorial sign may have had yet another reference within the manuscript. A few leaves further along, another pair of feet is treading the margins. It belongs to the tinted drawing of a nude female dancer on the first page of Physiognomia (fol. $25^{\mathrm{r}}$; Fig. 5). ${ }^{42}$ She cuts a striking figure, all the more so for being the only pictorial element, besides the line-drawings of the manicules and pedicules, that is not an integral part of a historiated initial or an initial's border extension. Much admired for its naturalism and the dynamic depiction of the dancer's movements, the drawing has lately been convincingly attributed to the first illuminator, who painted the more conventional and schematic figures in the historiated initials. ${ }^{43}$ The dancer may therefore already have been in place when the pedicules were drawn.

Attempts at directly relating the dancer to the contents of the treatise that she accompanies have remained very tentative; rather, she is likely not a commentary on or illustration of the text but relates to the figure of a nude man in the historiated initial. ${ }^{44}$ In doing so, she, can be considered meta-commentary: she playfully exemplifies the relationship between marginal paracontent and content, not by meaningfully engaging with that content but by drawing attention to how this relationship is given visible form on the page. At the same time, however, her sheer size, her movement and the erotic meaning that dancing, let alone nude female dancers, carry in medieval iconography, easily overshadow the formulaic representation of the man, tiny by comparison, in the initial. In this ostentatious subversion that ultimately does not disrupt but rather emphasizes the order of the page, the dancer plays a role that has been observed for pictorial marginalia in many manuscripts of the time. ${ }^{45}$

42 For a more detailed discussion of the drawing, see Volpera 2018, 46; Gamper and Marti 1998.

43 Volpera 2018, 46.

44 Gamper and Marti 2018; Volpera 2018, 46-47, agrees with Gamper and Marti's view that the drawing of the female dancer directly refers to the nude man in the initial but suggests that the woman, with her thick tresses, may allude to widely-held views that women's strong hairgrowth was a symptom of their predominantly wet and cold temperament.

45 For instance, Illich emphasizes the disruptive effect of the 'circus of fantasy creatures, often a jungle which threatens to invade and overpower the alphabetic component of the page'; Illich 1993, 110. Michael Camille, in his seminal book on marginal imagery, on the other hand, 
While there is little to find in the contents of Physiognomia that could constitute a plausible point of reference for the illuminator's striking choice, seductive women were linked to Aristotle by legend and spuriously attributed works. The story of his falling prey to the advances of Alexander the Great's lover, Phyllis, as an exemplum of men's folly in the face of beautiful women was wellknown and occasionally depicted at the time. ${ }^{46}$ Book I of De secretis secretorum is the source of another tale about the dangers of women. It contains a chapter, numbered 22 in the Eisenbibliothek manuscript, in which Aristotle warns Alexander not under any circumstances to trust women. He refers to an event in which only his own wisdom and circumspection saved Alexander from an assassination plot by the queen of India involving a 'poison-maiden', a young woman who had been fed venom until her very gaze had become deadly. ${ }^{47}$

Whether originally intended or not, the drawing became a source of inspiration not only for the pedicules but also for a pronounced interest of later users in the topic of women in the Aristotelian part of the manuscript. The dancer scandalized at least one reader. The most offending part of her anatomy was erased, and below her feet, a passage was added in the fourteenth century that describes woman as, inter alia, 'man's confusion' and an 'insatiable beast' ${ }^{48}$ It is a variation of a well-known and often-expanded excerpt from another philosopher's, Secundus the Silent's, advice to an emperor. The quote from the Vita Secundi philosophi could be used to express both a degree of learning and to reiterate the misogynism that De secretis secretorum expresses elsewhere in the manuscript..$^{49}$ In the Eisenbibliothek manuscript, further marginal annotations

has emphasized the ultimately stabilizing, affirmative effect of such transgressions; Camille 2010.

46 A roughly contemporary depiction of the scene in a manuscript of Brunetto Latini's Livre dou tresor is found in Carpentras, Bibl. Inguimbertine, MS 269, fol. 108 ${ }^{\mathrm{r}}$. See Roux 2009, 282, Fig. 27 and Pl. IV; Wimmer 2020, 279-281. For further depictions of Aristotle and Phyllis from the thirteenth and fourteenth centuries, see e. g. Herrmann 1991, and for examples of pictorial marginalia, see Randall 1966, Figs 554-557.

47 According to the critical edition, the passage is in Book I, 21; Steele 1920, 60. On the story of the 'poison-maiden', which does appear to have its origins in India, see Hertz 1905.

48 Gamper and Marti 1998 date the writing to the fourteenth century.

49 'Quid est mulier. Hominis confusio, insatiabilis bestia, continua solicitudo, indeficiens pugna, damnum cottidianum, domus tempestatis, solacii impedimentum'. Gamper and Marti 1998 read 'insanabilis bestia', but 'insatiabilis', favoured also by Volpera 2018, 48, who first identified the annotation as a quotation, seems the more likely transcription. It is also more commonly found in other manuscripts; see Brown 1920, 480, who first pointed out that ' $[\mathrm{t}] \mathrm{he}$ "Mulier" passage is frequently found detached from its context as a bit of monastic wisdom' in manuscripts. This is not to say, however, that the presence of the phrase is an indication of a 
in this treatise indicate another reader's particular interest in women's abilities, not least the dangerous ones. Scattered among numerous nota ligatures and two manicules, only a few notes, some ten in total, mention content matter. Some topics seem to have been of particular interest, being mentioned twice: the effects of wine, positive and adverse (fol. $7^{\mathrm{v}}$ ); vomiting (fols $6^{\mathrm{v}}, 7^{\mathrm{v}}$ ); and young women. The first of these two notes on 'puelle' highlights a passage that reports that learning used to be so widespread in Greek society that even a girl could occasionally be highly educated (fol. $4^{\mathrm{r}}$ ). ${ }^{50}$ The second note marks the story of the 'poison-maiden' ('exemplum puelle venenose', fol. $4^{\mathrm{v}}$ ). Thus, the marginal dancer becomes part of a marginal discourse spanning parts of the Aristotelian section of the manuscript.

\section{Conclusion}

In conclusion, the Eisenbibliothek manuscript is non-homogenous not only at a macro-level, consisting of three codicological units that were, to some degree, unified by being rubricated and illuminated in the same workshop. Rather, a closer look at the contributions of the craftsmen at the workshop reveals that even this unifying production layer consists of micro-layers that show a remarkable degree of interaction, corrections, and additions. Some of these contributions and interventions build a verbal and pictorial marginal discourse on the production and the use of books, a discourse that is gradually extended and reinterpreted by the users of the manuscript as they build new connections and cross-references between the book's contents and paracontents.

\section{Acknowledgements}

I would like to thank Bruno Reudenbach for his very useful feedback on an earlier draft of this paper.

monastic context here, all the more so as the instances of antonomasia enumerated here do not include those in Brown's transcriptions that explicitly refer to dangers to men's chastity, such as 'castitatis impedimentum' or 'incontinentis viri naufragium'.

50 Book I,21 in this manuscript but Book I,22 in the critical edition; Steele 1920, 58-59. 


\section{References}

Brown, Carleton (1920), 'Mulier est Hominis Confusio', Modern Language Notes, 35: 479-482. Camille, Michael (2010), Image on the Edge: The Margins of Medieval Art, London: Reaktion Books [1st edn: 1992].

Carruthers, Mary (2005), The Book of Memory: A Study of Memory in Medieval Culture (Cambridge Studies in Medieval Literature, 10), Cambridge: Cambridge University Press.

Flüeler, Christoph (2020), 'Illuminierte Aristoteleshandschrift aus Genua', in Marina Bernasconi Reusser, Christoph Flüeler and Brigitte Roux (eds), Die schönsten Seiten der Schweiz. Geistliche und weltliche Handschriften / Trésors enluminés de Suisse, exhib. cat. St Gall, Stiftsbibliothek, March-November 2020, and Cologny, Fondation Martin Bodmer, Spring 2022, Cinisello Balsamo, Milan: Silvana Editoriale, cat. no. 64, 284-285.

Fronska, Joana (2019), 'Writing in the Margin - Drawing in the Margin: Reading Practices of Medieval Jurists', in Rosalind Brown-Grant, Patrizia Carmassi, Gisela Drossbach, Anne D. Hedeman, Victoria Turner and Iolanda Ventura (eds), Power and the Paratext: Inscribing Knowledge in the Medieval Book (Studies in Medieval and Early Modern Culture, 66), Kalamazoo: Medieval Institute Publications, 141-159.

Gamper, Rudolf (1998), 'Ein fürstliches Kompendium aus dem 13. Jahrhundert: Die AristotelesAlbertus Magnus Handschrift der Eisenbibliothek', Ferrum. Nachrichten aus der Eisenbibliothek, Stiftung der Fischer AG, 70: 42-50, 61-62, 155-158.

Gamper, Rudolf and Susan Marti (1998), Katalog der mittelalterlichen Handschriften der Stadtbibliothek Schaffhausen, Zurich: Graf.

Grabmann, Martin (1934), 'Eine für Examenszwecke abgefaßte Quaestionensammlung der Pariser Artistenfakultät aus der ersten Hälfte des XIII. Jahrhunderts', Revue néoscolastique de philosophie, 41: 211-229.

Gumbert, J. Peter (2004), 'Codicological Units: Towards a Terminology for the Stratigraphy of the Non-Homogenous Codex', in Edoardo Crisci and Oronzo Pecere (eds), Il codice miscellaneo. Tipologie e funzioni. Atti del Convegno internazionale, Cassino 14-17 maggio 2003 (Segno e testo, 2), Cassino (Frosinone): Università degli studi di Cassino, 17-42.

Hamburger, Jeffrey (2009), 'Openings', in Gregory Kratzmann (ed.), Imagination, Books and Community in Medieval Europe: Papers of a conference held at the State Library of Victoria, Melbourne, 29-31 May 2008, in conjunction with an exhibition 'The Medieval Imagination', 28 March-15 June 2008, South Yarra, Vic.: Macmillan, 50-133.

Herrmann, Cornelia (1991), 'Der gerittene Aristoteles': Das Bildmotiv des 'gerittenen Aristoteles' und seine Bedeutung für die Aufrechterhaltung der gesellschaftlichen Ordnung vom Beginn des 13. Jahrhunderts bis um 1500 (Kunstgeschichte, 2), Pfaffenweiler: Centaurus. Hertz, Wilhelm (1905), 'Die Sage vom Giftmädchen', in Friedrich von der Leyen (ed.), Gesammelte Abhandlungen von Wilhelm Hertz, Stuttgart: J. G. Cotta'sche Buchhandlung Nachfolger, 156-277.

Illich, Ivan (1993), In the Vineyard of the Text: A Commentary to Hugh's Didascalicon, Chicago: University of Chicago Press [translation of L'Ère du livre, Paris: Les Éditions du Cerf 1990; German translation Im Weinberg des Textes. Frankfurt am Main: Luchterhand 1991].

Lewis, Suzanne (1992), 'Beyond the Frame: Marginal Figures and Historiated Initials in the Getty Apocalypse', The J. Paul Getty Museum Journal, 20: 53-76.

Morgan, Nigel J. (1988), Early Gothic Manuscripts, vol. 2 (A Survey of Manuscripts Illuminated in the British Isles, 4,2), London: Harvey Miller. 
Parkes, Malcolm B. (1976), 'The Influence of the Concepts of Ordinatio and Compilatio on the Development of the Book', in J. J. G. Alexander and M. T. Gibson (eds), Medieval Learning and Literature: Essays Presented to Richard William Hunt, Oxford: Clarendon Press, 127-28.

Pompe, Hedwig (2003), 'Eine Handreichung zum Thema', in Matthias Bickenbach, Annina Klappert and Hedwig Pompe (eds), Manus Loquens: Medium der Geste - Gesten der Medien, Cologne: DuMont, 8-25.

Randall, Lilian M. C. (1966), Images in the Margins of Gothic Manuscripts (California Studies in the History of Art, 4), Berkeley: University of California Press.

Reudenbach, Bruno (2009), 'Der Codex als heiliger Raum. Überlegungen zur Bildausstattung früher Evangelienbücher', in Stephan Müller and Lieselotte Saurma-Jeltsch (eds), Codex und Raum (Wolfenbütteler Mittelalter-Studien, 21), Wiesbaden: Harrassowitz, 59-84.

Rouse, Richard H. and Mary A. Rouse (1982), 'Statim invenire. Schools, Preachers, and New Attitudes to the Page', in Robert Benson, Giles Constable and Carol D. Langham (eds), Renaissance and Renewal in the Twelfth Century, Oxford: Clarendon Press, 201-225.

Roux, Brigitte (2009), Mondes en miniatures: l'iconographie du Livre du Trésor de Brunetto Latini (Matériaux pour l'histoire, 8), Geneva: Droz.

Saenger, Paul (1982), 'Silent Reading. Its Impact on Late Medieval Script and Society', Viator, 13: 367-414.

Sandler, Lucy Freeman (1996), Gothic Manuscripts, 1285-1385 (A Survey of Manuscripts Illuminated in the British Isles, 5,2), London: Harvey Miller.

Sandler, Lucy Freeman (1998), 'Pictorial and Verbal Play in the Margins: The Case of British Library, Stowe MS 49', in Michelle P. Brown and Scot McKendrick (eds), Illuminating the Book: Makers and Interpreters. Essays in Honour of Janet Backhouse (The British Library Studies in Medieval Culture), London: British Library, 52-68.

Sandler, Lucy Freeman (2012), 'Scribe, Corrector, Reader: The Marginal Drawings of the Morgan Library Lumere as lais and their Maker', English Manuscript Studies 1100-1700, 17: 107-139.

Sarton, George (1930), 'Aristotle and Phyllis', Isis, 14: 8-11.

Schneider, Wolfgang Christian (2000), 'Geschlossene Bücher - offene Bücher. Das Öffnen von Sinnräumen im Schließen von Codices', Historische Zeitschrift, 271: 561-592.

Schneider, Wolfgang Christian (2009), 'Raum im Codex - Codex im Raum: Mittelalterliche Herrscher-Codices als visuelle Kommunikationsräume', in Stephan Müller and Lieselotte Saurma-Jeltsch (eds), Codex und Raum (Wolfenbütteler Mittelalter-Studien, 21), Wiesbaden: Harrassowitz, 127-184.

Sherman, William H. (2008), Used Books: Marking Readers in Renaissance England (Material Texts), Philadelphia: University of Philadelphia Press.

Solterer, Helen (1994), 'Seeing, Hearing, Tasting Woman: Medieval Senses of Reading', Com parative Literature, 46: 129-145.

Steele, Robert (ed.) (1920), Opera hactenus inedita Rogeri Baconi, Fasc. V: Secretum Secretorum cum glossis et notulis. Tractatus brevis et utilis ad declarandum quedam obscure dicta Fratris Rogeri. Accedunt anglicana ex arabico edita per A. S. Fulton; versio vetusta anglo-normanica nunc primum edita, Oxford: Clarendon Press.

Tumanov, Rostislav (2015), Das Kopenhagener Stundenbuch: Bildprogramm und Layout im Kontext spätmittelalterlicher Lektüre- und Andachtspraktiken (Sensus, 9), Cologne: Böhlau.

Volpera, Federica (2018), ‘ll ms. 20 dell'Eisenbibliothek di Schlatt: una nuova acquisizione per la produzione libraria nella Genova di tardo Duecento', Rivista di storia della miniatura, 22: $38-52$. 
Weisheipl, James A. (1964), 'The Curriculum of the Faculty of Arts at Oxford in the Early Fourteenth Century', Medieval Studies, 26: 143-185.

Wimmer, Hanna (2018a), Illustrierte Aristotelescodices: Die medialen Konsequenzen universitärer Lehr- und Lernpraxis (Sensus, 7), Cologne: Böhlau.

Wimmer, Hanna (2018b), “Narration und Typologie in der "Goldenen Biblia pauperum” (British Library, Kings MS 5)', in Daniela Wagner and Hanna Wimmer (eds), Heilige Bücher - Leiber - Orte. Festschrift für Bruno Reudenbach, Berlin: Reimer, 109-120.

Wimmer, Hanna (2020), 'Of venerable teachers and boisterous students: Maistre Brunetto and the Arabic Aristotle', in Laura Cleaver, Alixe Bovey and Lucy Donkin (eds), Illuminating the Middle Ages: Tributes to Prof. John Lowden from his students, friends and colleagues (The Manuscript World, 12; Library of the Written Word, 79), Leiden: Brill, 276-290.

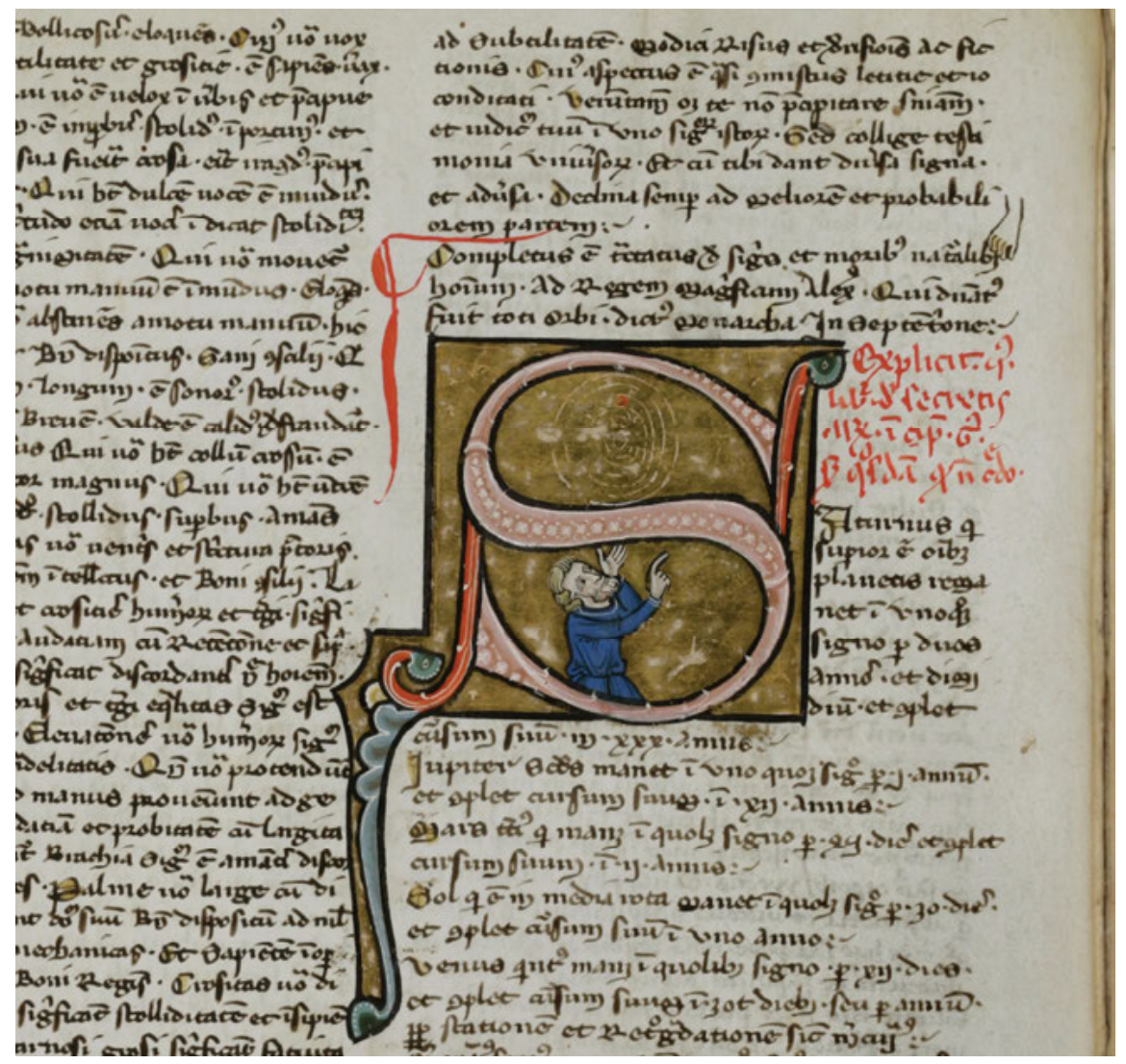

Fig. 1: A foot in the margin of the pseudo-Aristotelian De secretis secretorum. Italy (Genoa?), second half of the thirteenth century. Schlatt, Eisenbibliothek, MSS 20, fol. $14^{v}$ (<www.e-codices.ch〉). 


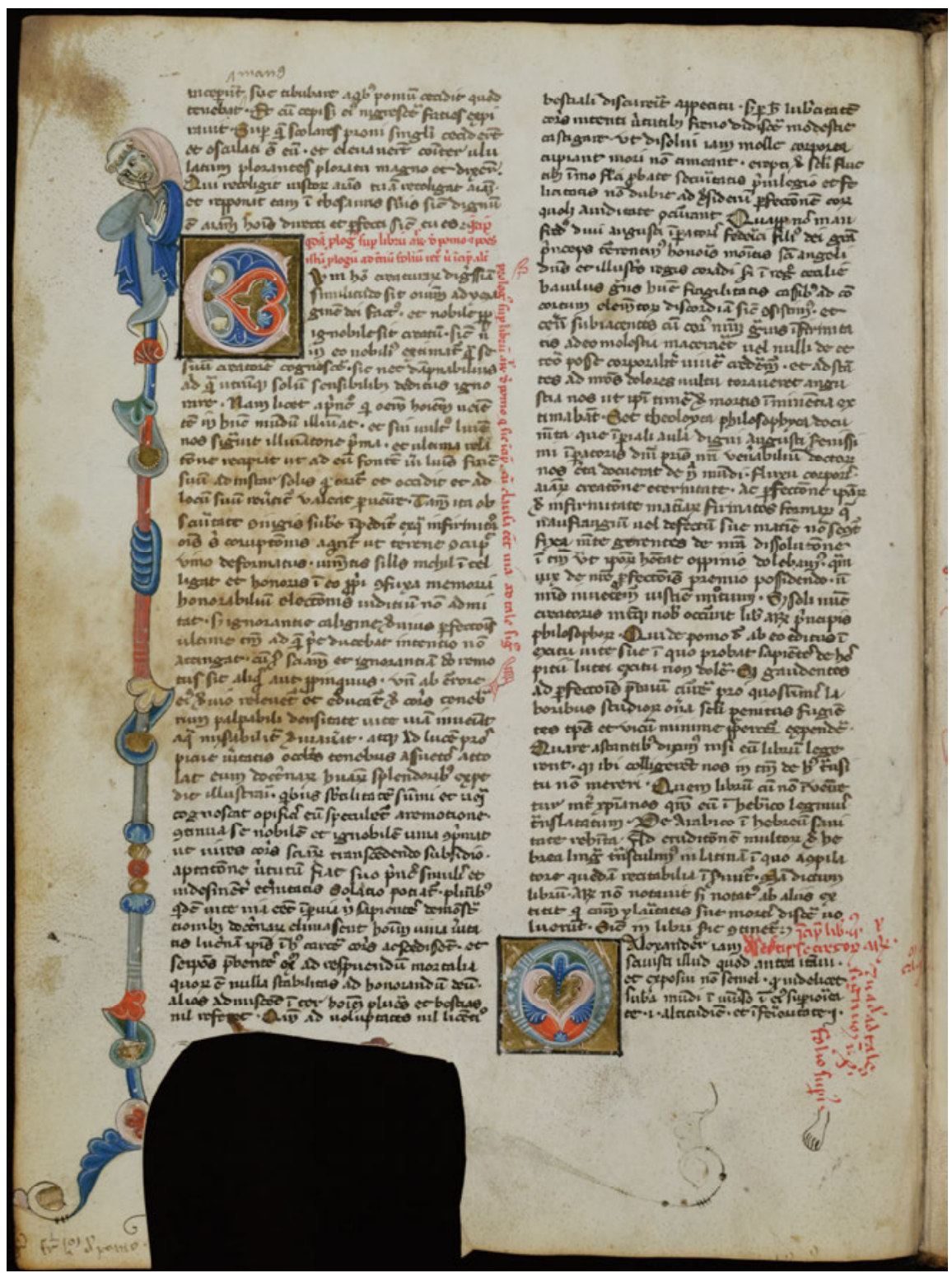

Fig. 2: A manicule and a pedicule helping to allocate substantial corrigenda to the pseudoAristotelian De secretis and De pomo. Schlatt, Eisenbibliothek, MSS 20, fol. $17^{\mathrm{v}}$ (<www.e-codices.ch〉). 


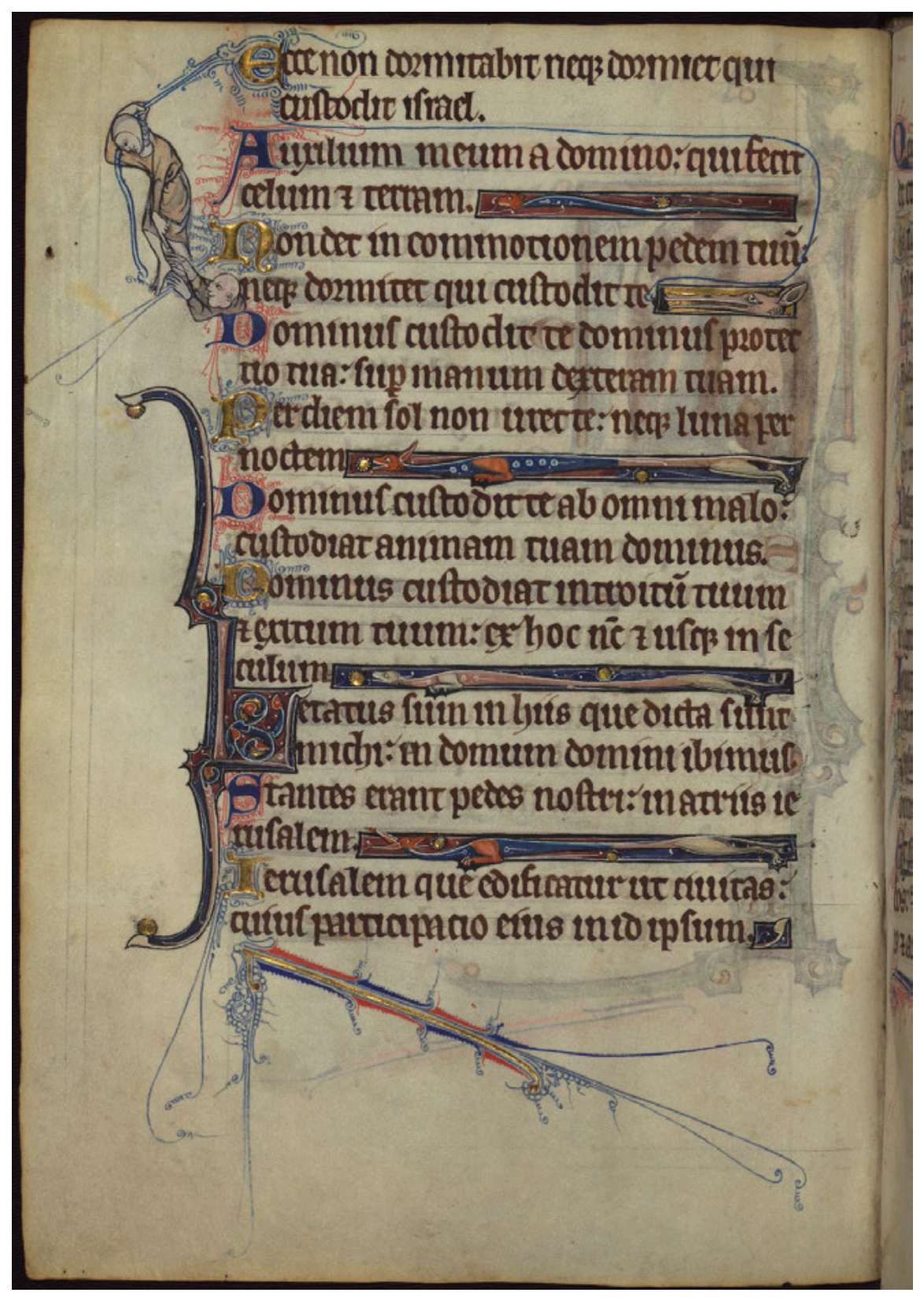

Fig. 3: Marginal labourers in a book of hours. England, c. 1300. Baltimore, Walters Art Museum, Walters MS W.102, fol. 39v ( $)$ The Walters Art Museum. 


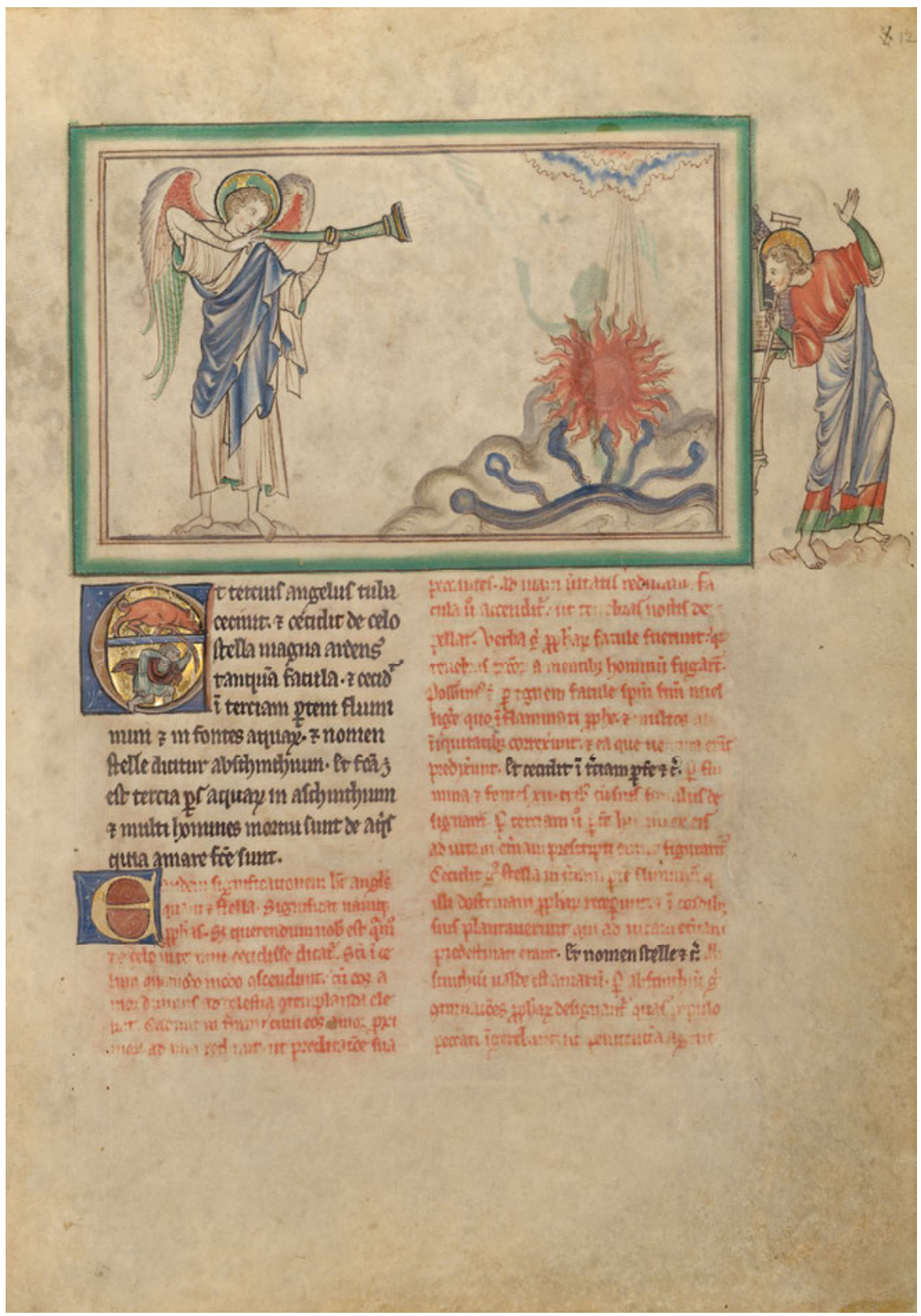

Fig. 4: St John, walking stick in hand, witnessing the blowing of the Third Trumpet. Getty Apocalypse, England, c. 1255-1260. Los Angeles, The J. Paul Getty Museum, MS Ludwig III 1, fol. 12'. Digital image courtesy of the Getty's Open Content Program. 


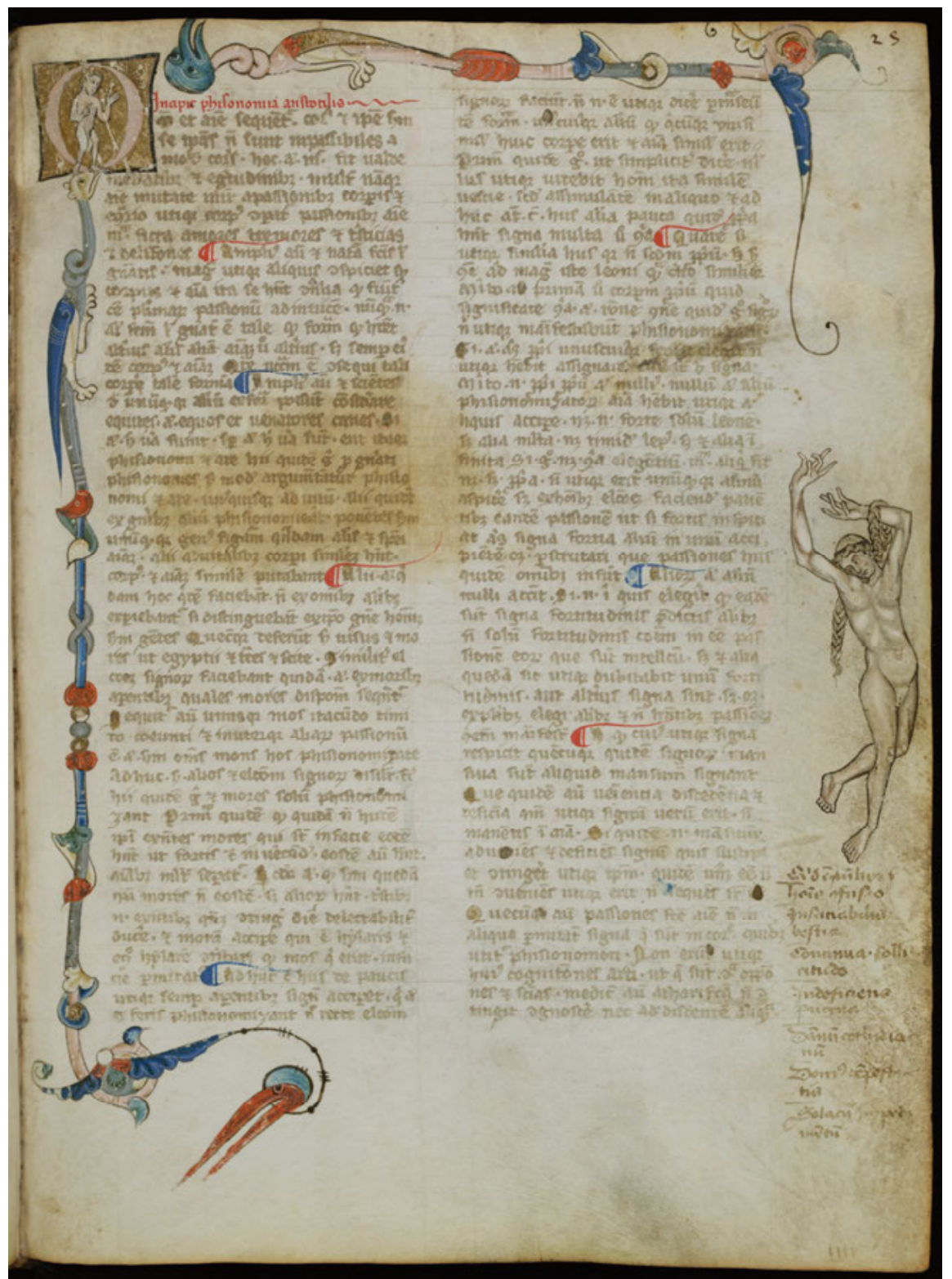

Fig. 5: A nude dancer in the margins of the ps.-Aristotelian Physiognomia. Schlatt, Eisenbibliothek, MSS 20, fol. $25^{\text {r }(<w w w . e-c o d i c e s . c h ~}>$ ). 